\title{
Instability Analysis of a Low-Angle Low-Expansive Soil Slope under Seasonal Wet-Dry Cycles and River-Level Variations
}

\author{
Yongzheng Qi, ${ }^{1,2}$ Zongzhi Wang $\mathbb{D}^{3}{ }^{3}$ Haoqing $\mathrm{Xu},{ }^{2}$ and Zirui Yuan ${ }^{2}$ \\ ${ }^{1}$ College of Civil and Transportation Engineering, Hohai University, Xikang Road, Nanjing 210098, China \\ ${ }^{2}$ School of Civil Engineering and Architecture, Jiangsu University of Science and Technology, Mengxi Road, Zhenjiang 212000, \\ China \\ ${ }^{3}$ State Key Laboratory of Hydrology-Water Resources and Hydraulic Engineering, Nanjing Hydraulic Research Institute, \\ Nanjing 210029, China
}

Correspondence should be addressed to Zongzhi Wang; wangzz77@163.com

Received 1 January 2020; Revised 14 February 2020; Accepted 20 April 2020; Published 14 May 2020

Academic Editor: Yuqing Zhang

Copyright (C) 2020 Yongzheng Qi et al. This is an open access article distributed under the Creative Commons Attribution License, which permits unrestricted use, distribution, and reproduction in any medium, provided the original work is properly cited.

There were a small amount of obvious offsets at the bearing of bridge piers built on an artificial gentle canal bank terrace and many tensile cracks visible at the surface of the mortar block stones covering the terrace soil in several years following construction. To determine these reasons, a comprehensive site investigation and a wide variety of tests were implemented, which included geophysical tests, in situ tests, laboratory tests, pile integrity detection, and numerical analysis with the finite element method (FEM). The results revealed that the soil of the low-angle slope was the potentially low-expansive clay soil. The reduction in soil shear strength deriving from seasonal wet-dry cycles and river-level variations led to the instability and failure of the low-angle low-expansive soil slope, which triggered the collapses of the soil slope and lots of fractures in the piles of the bridge foundation. The typical characteristics of the instability and failure of the low-angle low-expansive soil slope were tractional detachment and slow sliding.

\section{Introduction}

Expansive soil failure events are not as dramatic as earthquakes or hurricanes. The failure soil occurs more slowly than those in other disasters, and the damage may not be concentrated in a small location but instead spread over wide areas. At times, expansive soil damage may considerably worsen and cause very large disasters despite minor maintenance and visual inspections [1]. Expansive soil is the special clay that undergoes expansion, shrinkage, fissuring, and superconsolidation in natural geological processes. Expansive soil is sensitive to climatic and hydrological conditions. Additionally, it exhibits many consistent and long-term potential characteristics. Expansive soils can be found on almost all continents. The destructive effects of these clay soils appear all over the world, such as China, India, Australia, Canada, the United States, Israel, and South Africa [2]. According to the statistics provided by Steinberg, the annual loss caused by expansive soil damage is US $\$ 10$ billion in the United States and up to $¥ 100$ million in China. Because the expansive soil expands, cracks, and overconsolidates, it is called "engineering cancer," and a sliding failure of a slope with a slope angle only between $16.7 \%$ and $25 \%$ is usually caused by the presence of highly expansive soil [3]. When this type of soil dries, the remaining moisture concentrates near the particle interface, forming menisci, and the particles are pulled closer together by the resulting surface tension forces, which cause the soil to shrink [1].

Regarding the instability mechanism of expansive soil slopes, it is generally believed that the instability of expansive soil slopes is characterized by shallow soil layers (normally less than $3 \mathrm{~m}$ ), step-by-step traction, and low-angle slope sliding. The wet and dry cycles (rainfall and evaporation) easily trigger swelling and shrinkage cracking of the shallow expansive soil. The fracturing accelerates water infiltration, destroys the soil structure, and thus leads to a decrease in soil strength [4]. Shallow slope failure may take place during the wet season following construction $[5,6]$. The effect of 
precipitation on slope instability was analyzed based on Liu and $\mathrm{Li}$ in the case of an actual landslide [7]. The instability of the soil slope can be severely impacted by precipitation, infiltration, and variation in water level. The wet-dry cycle leads to cracking of the expansive soils in the slope. The widths and depths of the fractures will increase with the number of wet-dry cycles. The fractures not only weaken the soil structure of the slope but also provide conduits for water penetration. This further leads to softening soil and decreasing strength. Each wet-dry cycle results in the accumulation of the downward settlement and horizontal displacement of the slopes. With the increase in the number of wet-dry cycles, the expansive soil slopes gradually became damaged, regardless of the soil density [8].

Based on the results of previous studies [9, 10], precipitation might cause shallow slope composed of plastic clay soil to failure due to reduction in its shear strength caused by soil softening. The rainwater easily intrudes the soil due to existing desiccation cracks that formed during the dry period. Low-permeability soils stop the downward intrusion of rainwater. Consequently, both excess pore water pressure and reduced shear strength have led to slope sliding several years after its completion [11].

The shear strength of expansive soil slope may decrease on account of swell-shrink behavior following construction, and slope failure often occurs in shallow regions of slope. The sliding interface is normally parallel to the slope surface [12]. Instability of the slope can take place a few years or even decades following construction.

The water level fluctuation caused by tides, irrigation, freshwater recharge, and hydropower production also influences the stability of soil slope. Cyclical fluctuation of the water level in reservoir often results in the failure of its bank slope. Water-level fluctuation can cause landslide to reactivate. Slope instability will occur during not only water level drawdown but also water level rise [13]. Slope instability is related to fluctuation of water level [14]. Slope soil is susceptible to variations in water level, and shear strength of fully softened soil will change accordingly. The safety factor of soil slope will alter due to variation in water level [15]. Consequently, the relationship of slope instability and water level fluctuation should be researched and evaluated.

The slope instability of expansive soil slope of a canal located in Nanjing, East China, was analyzed in this paper using cone penetration tests (CPTs), standard penetration tests (SPTs), standard soil tests, soil potential expansion tests, and finite element method (FEM) numerical analysis. The soil shear strength was attained by using various shear strength tests, such as direct shear tests and triaxial tests. The analysis of slope instability in ABAQUS [16] was conducted according to the parameters determined from the soil tests.

\section{Background}

The slope investigated during this study is an artificial canal slope of accumulated canal bank terrace and is located in the southeast corner of Nanjing, East China. The slope soil attained by dredged river clay across the site was fairly uniform. The slope was relatively gentle, as is presented schematically in Figure 1. The vertical height of the slope is approximately $16.6 \mathrm{~m}$ with slope angles ranging from $8.3 \%$ to $15.5 \%$. The highest point of the slope is in the south of the study area, and the lowest point is in the north. There are 3 steps with slope covered with stone masonry, as shown in Figures 2(a)-2(c). The slope protection is approximately $50 \mathrm{~m}$ wide along the canal and approximately $80 \mathrm{~m}$ long perpendicular to the canal.

It was observed in the seventh year after its construction that a small amount of offset had occurred at the bearing of bridge piers \#1 \#4 built on the canal slope, and there were many tensile cracks visible at the surface of the stone masonry covering above the slope. It was speculated that instability of the canal slope might be triggered due to several seasonal wet-dry cycles and the variation in river level. When the bridge was examined in the ninth year after its construction, the magnitude of the bearing offset at the top of piers \#1 \#4 was larger than ever before, and the offset was accelerating. A comprehensive inspection of the slope and the bridge built on it was carried out ten years after its construction. The investigation results revealed that the bearing offset of pier \#2 was $23 \mathrm{~cm}$ and that the bearing offset of pier \#1 was $18 \mathrm{~cm}$. There were many wider tensile cracks at the surface of the stone masonry covering above the slope, as shown in Figure 2(c). There was a thoroughgoing cross fracture in the asphalt concrete road approximately $20 \mathrm{~m}$ away from the crest of the slope, as shown in Figure 2(d). The piers of the bridge built on the slope had clearly moved in the direction of the riverbed, northwardly. The maximum offset of pier \#3 was $44.5 \mathrm{~cm}$, and the vertical tilt of pier \#4 was the largest, $1.52 \%$, as shown in Table 1 .

The ground-water level is dominantly controlled by precipitation and the lateral recharge of rivers. Rainfall is mainly produced by natural evaporation and discharge of rivers.

The lowest river water level of the canal is $6 \mathrm{~m}$ and occurs in winter. The river water level rises slowly from April to June and rapidly during July and August to the highest river water level, which is absolute height of $8.9 \mathrm{~m}$ above mean sea level. The river water level drops rapidly from September to October and then gradually decreases to the lowest river water level in January. The absolute height of the riverbed above mean sea level is $3.6 \mathrm{~m}$.

\section{Ground Investigation}

The ground investigation included collecting soil samples from six groups of test boreholes, named $\mathrm{BH} 1, \mathrm{BH} 2, \mathrm{BH}$, $\mathrm{BH} 4, \mathrm{BH} 5$, and $\mathrm{BH} 6$. $\mathrm{BH} 1$ was situated adjacent to the crest of the slope, $\mathrm{BH} 2, \mathrm{BH} 3, \mathrm{BH} 4$, and $\mathrm{BH} 5$ were situated in the medium of the slope, and BH6 was situated at the toe of the slope. The soil samples collected in situ from the site were tested to evaluate the index properties and shear strength parameters of the slope soil. The test results were then utilized in FEM simulations. The ground investigation was implemented by using SPTs and CPTs. The layout of the soil test borings is presented in Figure 3.

The drilling depth of test borehole $\mathrm{BH} 1$ was $25.45 \mathrm{~m}$. The drilling depths of the test boreholes $\mathrm{BH} 2, \mathrm{BH} 3, \mathrm{BH} 4, \mathrm{BH} 5$, 


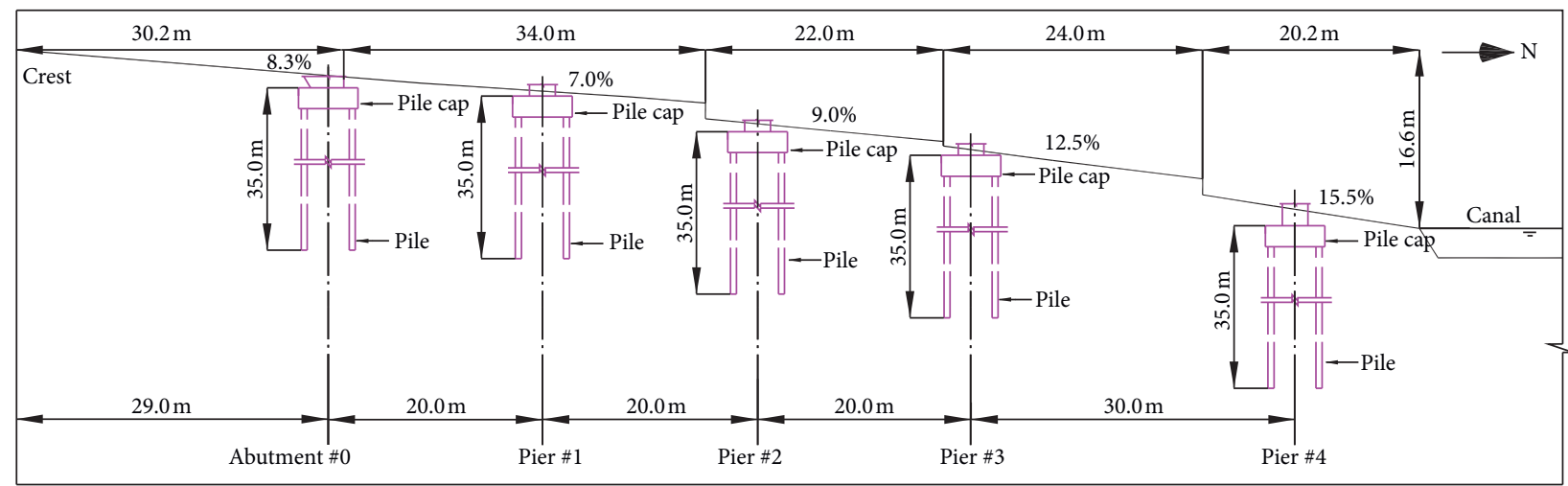

FIGURE 1: Schematic of the slope.

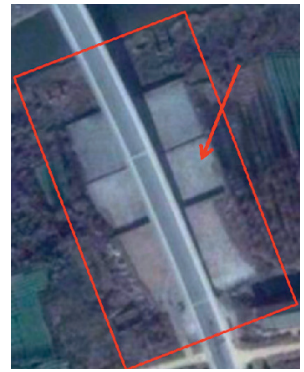

(a)

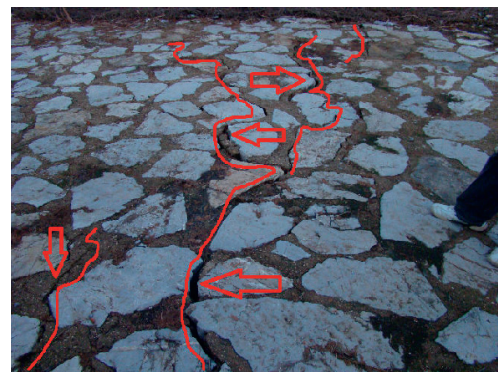

(b)

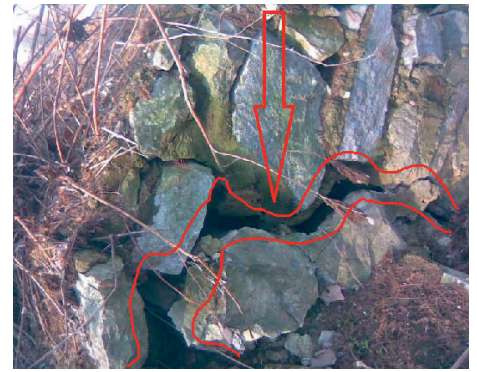

(c)

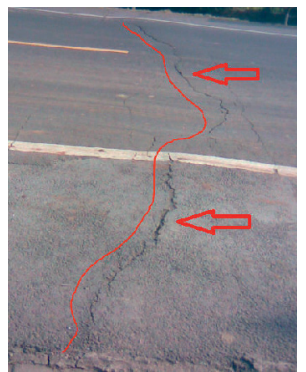

(d)

FIgURE 2: (a) Layout of the slope (plan view); (b, c) cracks in the stone masonry; (d) thoroughgoing cracks in the road.

TABLE 1: Measurement of the horizontal deviation and inclination of the piers.

\begin{tabular}{lcccc}
\hline $\begin{array}{l}\text { Pier or } \\
\text { abutment }\end{array}$ & $\begin{array}{c}\text { The bottom offset of piers to the } \\
\text { north }(\mathrm{cm})\end{array}$ & $\begin{array}{c}\text { The top offset of piers to the } \\
\text { north }(\mathrm{cm})\end{array}$ & $\begin{array}{c}\text { The pier height } \\
(\mathrm{m})\end{array}$ & $\begin{array}{c}\text { The total tilt of piers to the } \\
\text { south }(\%)\end{array}$ \\
\hline$\# 0$ & 6.5 & 6.3 & - & - \\
$\# 1$ & 29.8 & 28.8 & 4.380 & 0.58 \\
$\# 2$ & 35.0 & 34.9 & 6.937 & 0.40 \\
$\# 3$ & 44.7 & 44.5 & 9.386 & 0.01 \\
$\# 4$ & 31.4 & 17.0 & 1.52 \\
\hline
\end{tabular}

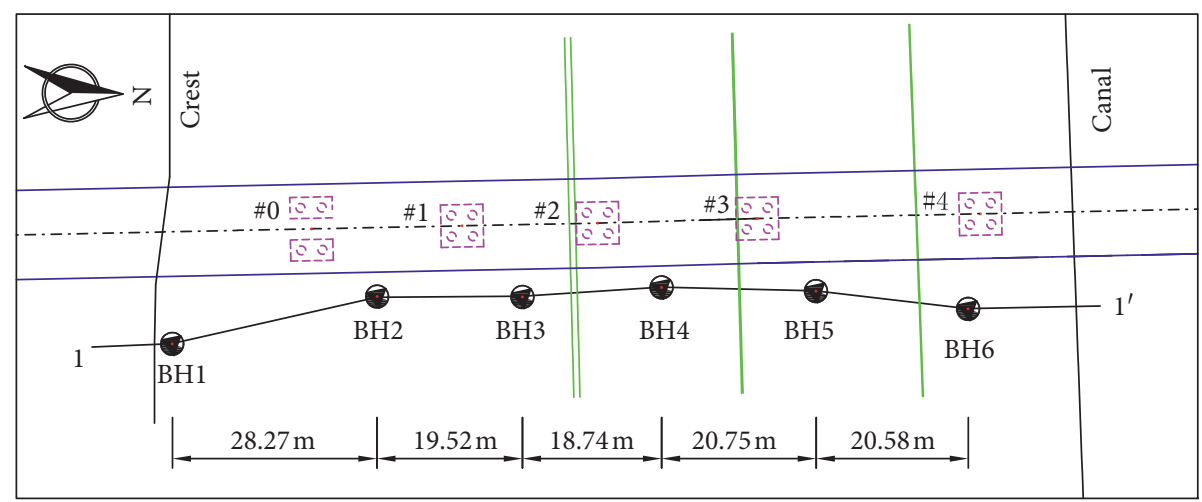

FIGURE 3: The layout of the soil borings. 
and BH6 were $20 \mathrm{~m}$. All the test borings were $110 \mathrm{~mm}$ in diameter.

3.1. Laboratory Tests. Index properties of the slope soil, including the water content (WC), plastic limit (PL), plasticity index (PI), and liquid limit (LL), determined from the laboratory tests of the soil samples are shown in Table 2 and Figure 4. According to the geological age and soil properties, the slope soils were divided into three soil layers, whose soil profile is shown in Figure 5(a). Soil layer 1, namely, "made ground," was loose yellowish grey clay mixed with macadam and plant roots. Soil layer 2 was greyish yellow clay interlayered with thin grey silty clay layers. Soil layer 3 was stiff yellowish brown clay with sparse iron manganese concretions and was partially mixed with gravel.

According to the results of the PI and LL tests, the PI and LL values of the slope soil ranged from 34.8 to 42.8 and 20.6 to 23.1 , respectively. The magnitude of the water content of the slope soil is presented in Table 2, which shows that the average water contents of soil layer 1 and soil layer 2 were $25.5 \%$ and $23.6 \%$, respectively, while soil layer 3 had moisture content of $21.7 \%$. The results of the soil tests were evaluated, as shown in Figure 4. The slope soil was categorized as low-plasticity clay (CL).

The coefficients of permeability of soil layer 1 and layer 2 were $4.5 \times 10^{-5} \mathrm{~cm} / \mathrm{s}$ and $7.8 \times 10^{-6} \mathrm{~cm} / \mathrm{s}$, respectively, while soil layer 3 had coefficient of permeability of $2.7 \times 10^{-7} \mathrm{~cm} / \mathrm{s}$, which indicates that the permeability of soil layer 1 and soil layer 2 was only slightly permeable and that of soil layer 3 was nearly impermeable. There was ground-water in soil layer 1 and layer 2 in the vicinity of the canal, and the ground-water level varied with the rise and fall of the river water level.

3.2. In Situ Tests. Six groups of boreholes, as shown in Figure 3(a), were drilled on the slope. Each group comprised two bore holes spaced $1 \mathrm{~m}$ apart. One borehole was drilled for the SPT and soil sampling; the other was drilled for the CPT. The soil CPT profile and soil parameters from the SPT values determined from $\mathrm{BH} 1$ to $\mathrm{BH} 6$ are shown in Figure 5. The variations in CPT value and SPT value with the depth are shown in Figures 5(a) and 5(b), respectively.

As shown in Figure 5(a), the variation in the CPT value with the depth of each borehole indicates that the CPT values of soil layer 1 were within 0.715 to $2.484 \mathrm{MPa}$ and those of soil layer 2 were within 0.835 to $3.358 \mathrm{MPa}$, while the CPT values of layer 3 ranged between 2.456 and $7.778 \mathrm{MPa}$, which were much higher than those of the upper two strata. Figure 5(b) shows that the SPT values ranged from 4 to 11, 6 to 21 , and 17 to 67 for soil layers 1,2 , and 3, respectively. The SPT values increased with depth, like the results of CPTs. The SPT values of soil layer 3 were much higher than those of the tow soil layers above, clearly indicating that the lower stratum had higher strength.

3.3. Estimating Potential Expansion. Expansive soil has the conspicuous clay content. Many types of testing and determination methods have been proposed, but none of them are generally applicable. In this paper, the magnitude of swelling is determined using the free swelling ratio, $\delta_{\mathrm{ef}}$, which is the percentage equal to the volume increment to the original volume of dry soil after steady expansion in water. The free swelling ratio tests were conducted in accordance with the GB50112-2013 guidelines. During the test, a dry soil specimen is remoulded into a $50 \mathrm{ml}$ graduated cylinder. The specimen is immersed in water to be fully saturated and is permitted to stand freely until the rate of swelling reaches a critical value. The free swelling ratio, $\delta_{\text {ef }}$, is expressed as

$$
\delta_{\mathrm{ef}}=\frac{v_{w}-v_{0}}{v_{0}} \times 100
$$

where $v_{w}$ is the final volume of the soil after expansion and $v_{0}$ is the initial volume of the specimen.

According to the typical classification of soil expansiveness based on free swelling ratio test results, the potential expansion of soil is very low, low, medium, and high when the free swelling ratio values range from 0 to 40,40 to 65,65 to 90 , and more than 90 , respectively.

The free swelling ratios of the soil samples from the study site at borehole $\mathrm{BH} 1$ are shown in Figure 6, which indicates that the potential expansion of soil layer 1 was very low and that the potential expansion of soil layers 2 and 3 was low.

As shown in Figure 6, the slope soil is potentially low expansive clay, which could result in many problems such as slope instability and foundation cracking [17].

3.4. Precipitation and Evaporation. Precipitation and evaporation [18] data of the project site in Nanjing, East China, were evaluated. These precipitation and evaporation data of Nanjing are used and are shown in Figure 7. The total annual precipitation and evaporation are very high and the highest occur during summer. In contrast, there are less precipitation and evaporation during the winter. That is, the wet summer is followed by the dry winter. The clay soil might have a high expansion due to the variation in water content, according to the results of Holtz and Kovacs [19]. Obvious shrinkage cracks might form due to wet-dry cycling, which would probably be used as the preferential flow path for water during precipitation. Because low-plasticity clay soil has weak osmosis property, rain water is likely to remain below the active area. Therefore, the instability of the slope due to soil strength reduction caused by precipitation requires analysis.

The depth of the active zone is a crucial parameter when analyzing the expansion of soil. The active zone [20] by the design can be taken as the zone of moisture content fluctuation. The engineering design also needs to consider how human activities affect soil expansion at the given site. The water condition may change due to human activities at the particular place; hence, the depth of the active zone is influenced as well. Because the fissures transport water to greater depth, heavily fissured soils will generally have deeper active zone. Field studies conducted in Colorado indicated that the studied active zone extended to $16 \mathrm{~m}$ below the ground surface in certain areas [21]. 
TABLE 2: The physical properties of the slope soil samples.

\begin{tabular}{|c|c|c|c|c|c|c|c|c|c|}
\hline $\begin{array}{l}\text { Layer } \\
\text { no. }\end{array}$ & Description & $\begin{array}{c}\text { Moisture } \\
\text { content } \\
w(\%)\end{array}$ & $\begin{array}{c}\text { Unit } \\
\text { weight } \\
\gamma\left(\mathrm{kN} / \mathrm{m}^{3}\right)\end{array}$ & $\begin{array}{c}\text { Void } \\
\text { ratio } \\
e\end{array}$ & $\begin{array}{c}\text { Liquid } \\
\text { limit } \\
W_{\mathrm{L}}\end{array}$ & $\begin{array}{c}\text { Plastic } \\
\text { limit } \\
W_{\mathrm{P}} \\
\end{array}$ & $\begin{array}{c}\text { Plasticity } \\
\text { index } \\
I_{\mathrm{P}}\end{array}$ & $\begin{array}{c}\text { Liquidity } \\
\text { index } \\
I_{\mathrm{L}}\end{array}$ & $\begin{array}{c}\text { Elastic } \\
\text { modulus } \\
E(\mathrm{MPa})\end{array}$ \\
\hline 1 & $\begin{array}{l}\text { Yellowish grey clay } \\
\text { (CL) }\end{array}$ & 25.5 & 19.0 & 0.823 & 37.7 & 22.5 & 15.1 & 0.26 & 5.49 \\
\hline 2 & $\begin{array}{l}\text { Greyish yellow clay } \\
\qquad(\mathrm{CL})\end{array}$ & 23.6 & 19.8 & 0.740 & 34.8 & 20.6 & 14.2 & 0.30 & 6.69 \\
\hline 3 & $\begin{array}{c}\text { Yellowish brown } \\
\text { clay }(\mathrm{CL})\end{array}$ & 21.7 & 19.9 & 0.682 & 42.8 & 23.1 & 19.6 & 0.07 & 8.52 \\
\hline
\end{tabular}

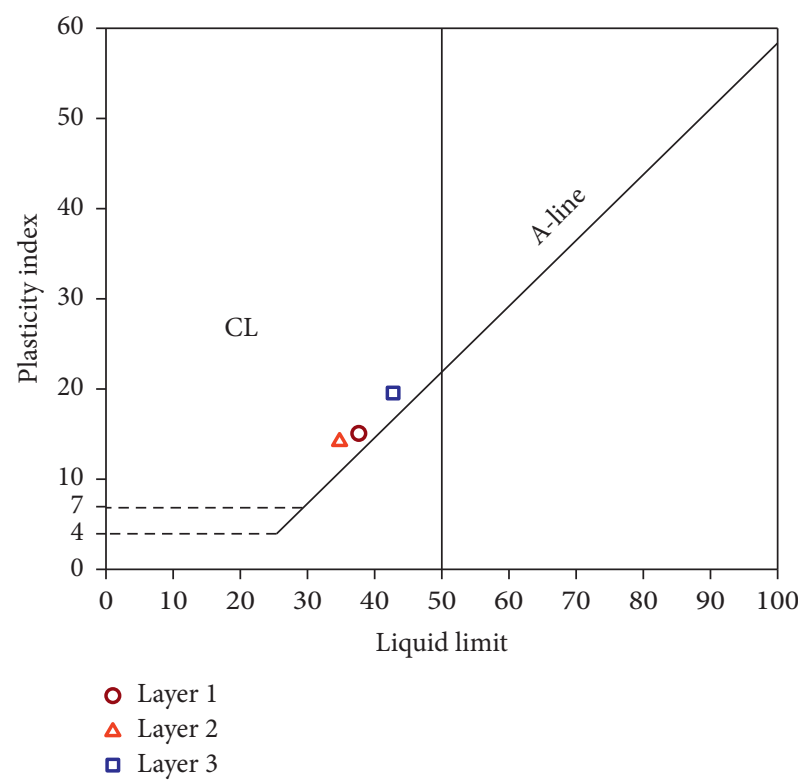

Figure 4: Plasticity chart.

If the site is in its natural state under the influence of climatic changes, without any influence of human activities, the water content of the soil underlying the site will vary more near the slope surface than deep underground. The reason for this trend is that the variations in precipitation and evaporation change more rapidly within these upper soils. It is assumed that the water content is approximately constant below this zone. Hence, no expansion occurs below this zone. It was determined from the precipitation and evaporation data that an approximate average depth of natural active zone in Nanjing, East China, is $3.0 \mathrm{~m}$ below the ground surface.

\section{Pile Integrity Detection}

The drilling core measurement method (DCM) is broadly utilized to detect the continuity of pile integrity and concrete quality [22]. The method is very simple and easily applied, whereas the discontinuities, especially fractures, in pile are very difficult to determine precisely. Fractures in pile are crucial to identify the evaluation of the safety of the whole structure. A borehole optical imaging system is an effective, convenient, and practical drilling investigation technology.
The interior status of the borehole can be directly observed from optical images [23, 24]. To establish the spatial coordinate system of the drilling hole, the diameter of the borehole must be known, and the shape of the borehole should be a standard cylinder. Therefore, the position and orientation of the panoramic image can be determined by utilizing a location method. A continuous orientated digital $360^{\circ}$ colour image of the borehole wall can be attained by borehole optical imaging technology. Thus, the continuous change in the borehole wall and the fractures in the pile can be directly surveyed [25]. In this paper, borehole optical imaging technology is used to obtain an image along the borehole wall in pile.

In the space beneath the bridge, piles 2 and 4 of pier \#3 and pile 1 of pier \#4, which was $1200 \mathrm{~mm}$ in diameter and $33 \mathrm{~m}$ in depth, were selected, as shown in Figure 8. The drilling hole in each pile is $35 \mathrm{~m}$ deep and $91 \mathrm{~mm}$ in diameter. All of the drilling holes were flushed after drilling to remove debris and broken stones and then swilled using clean river water. Finally, the selected piles were imaged with borehole optical imaging technology to identify fractures in the piles.

The typical borehole wall images of the fractures obtained at the site are presented with the depth of each pile drilling hole, in Figure 9, which shows the emerging fractures of piles 2 and 4 of pier \#3 and pile 1 of pier \#4. Figure 9 shows that there were 6 irregular fractures at a depth of $10.0 \mathrm{~m} \sim 14.0 \mathrm{~m}$ in pile 2 of pier \#3 and 10 irregular fractures at a depth of $10.0 \mathrm{~m} \sim 15.0 \mathrm{~m}$ in pile 2 of pier \#3, while there were 12 irregular fractures at a depth of $5.0 \mathrm{~m} \sim 12.0 \mathrm{~m}$ in pile 1 of pier \#4. From the results of the detected piles, it could be speculated that there were also many fractures in other unselected piles of the piers, which shows that the soil slope had undergone potential instability and failure. Additionally, as shown in Figure 9, the depth of the fractures observed in the piles of pier \#4 was shallower than that of pier \#3; at the same time, the depth range of the fractures observed in the piles of pier \#4 was greater. The depth of the potential slide interface in the soil slope could be derived from the depth of the fractures in the piles.

\section{Slope Instability Analyses}

The slope instability analyses were conducted by using the FEM program ABAQUS, which utilized the elastic-perfectly plastic Mohr-Coulomb soil model. During this study, 


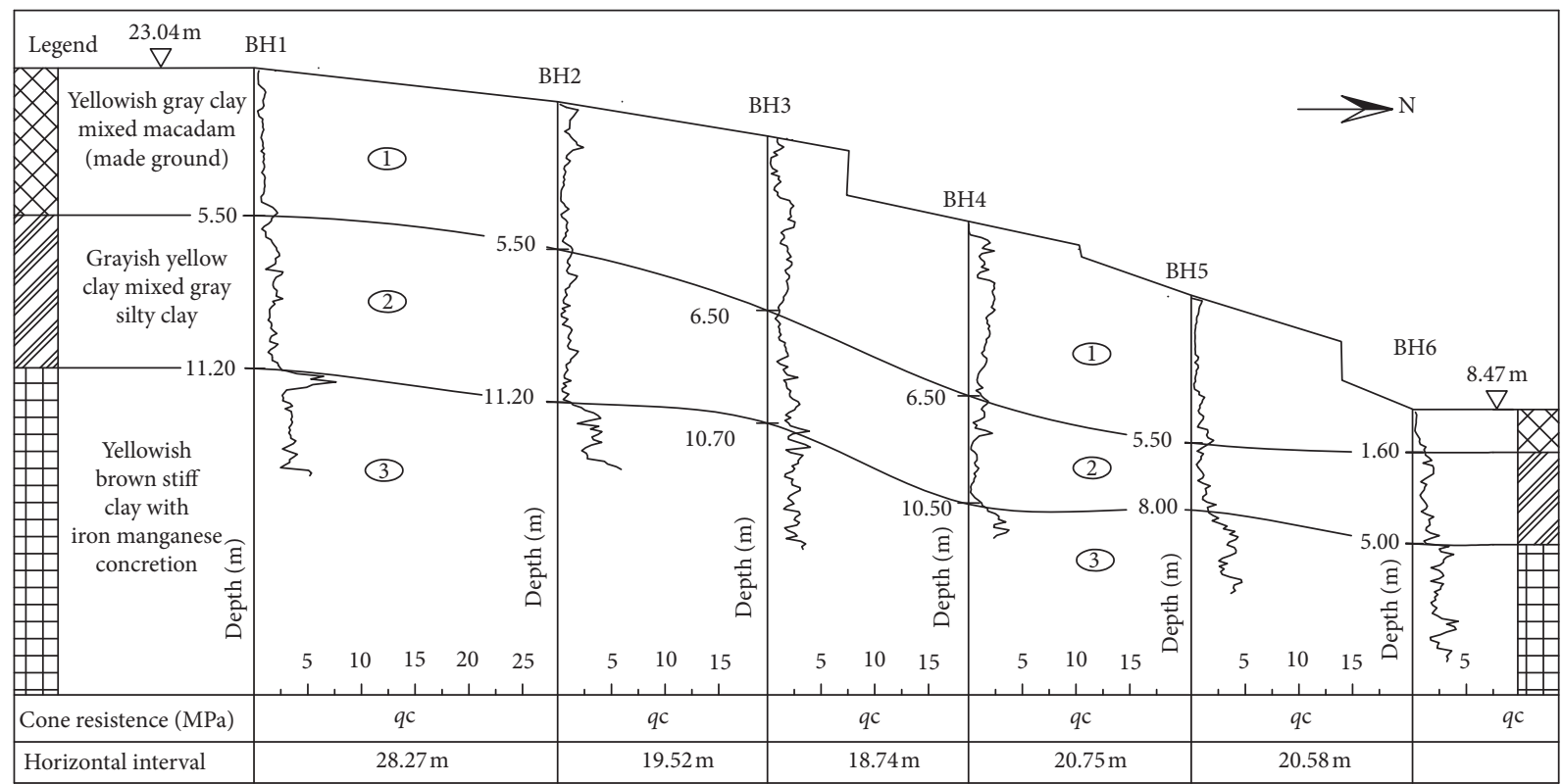

(a)
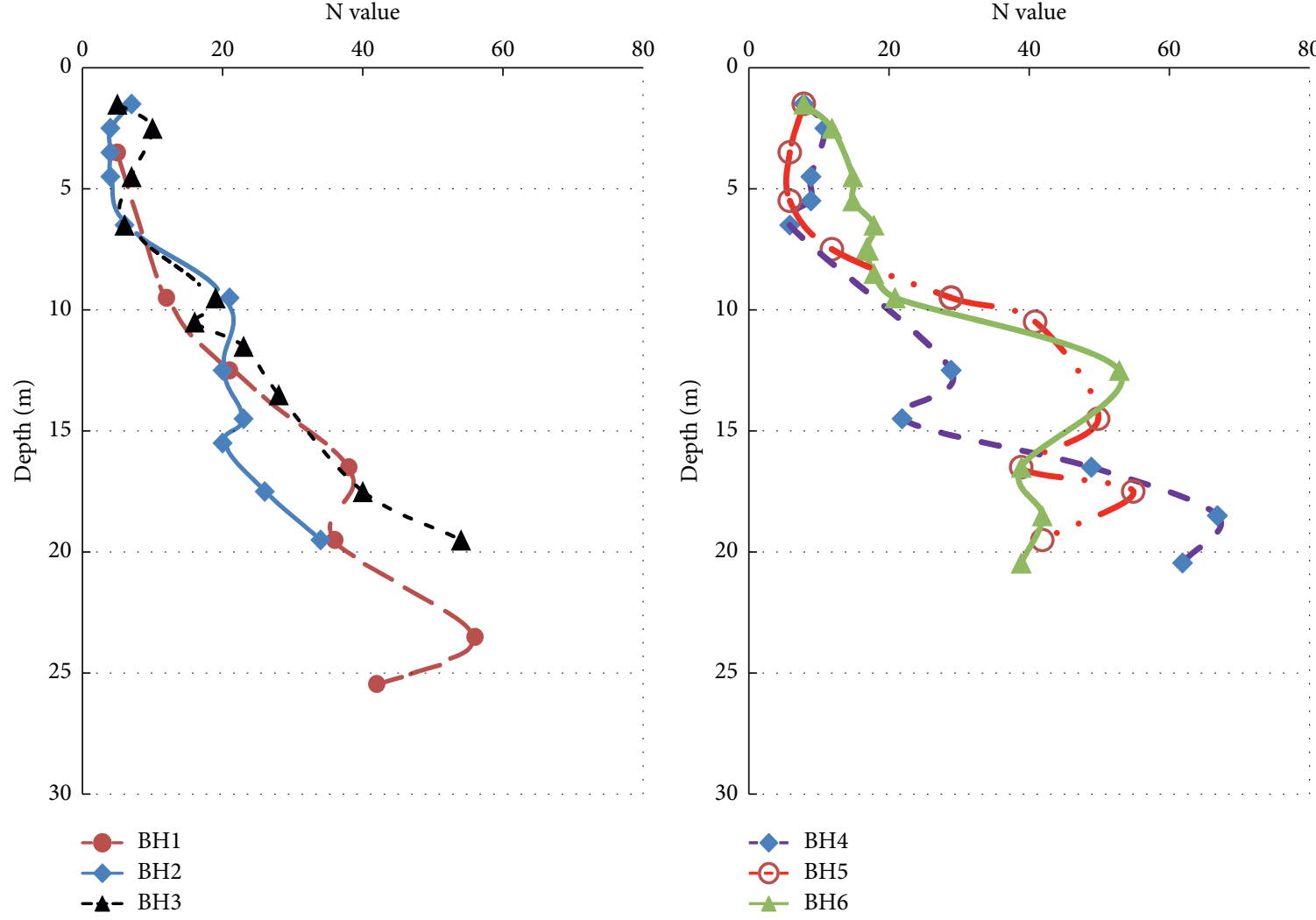

(b)

FIGURE 5: The results of the in situ tests: (a) CPT profiles (tip resistance); (b) the variation in SPT with borehole depth. 


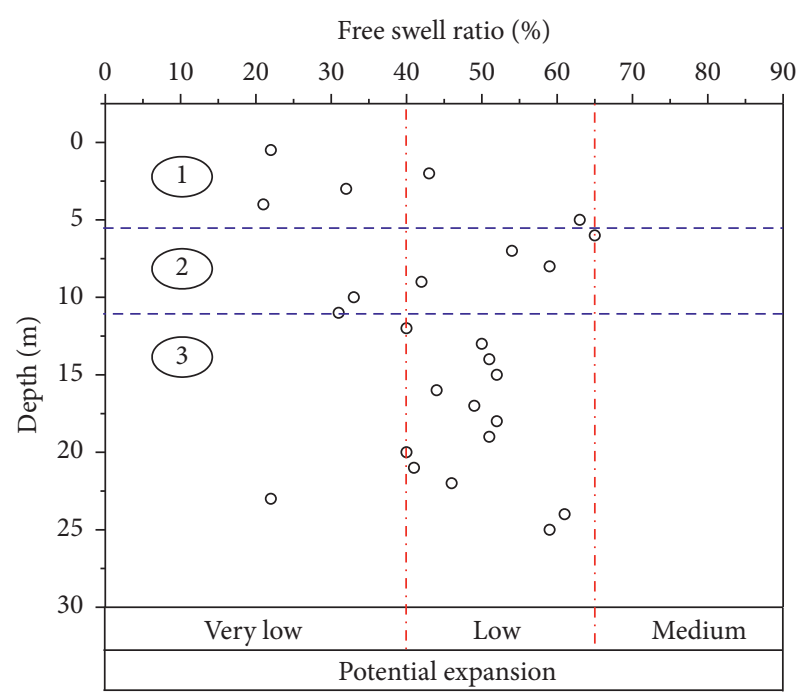

- $\mathrm{BH} 1$
Figure 6: The variation in the free swelling ratio test values with depth at $\mathrm{BH} 1$.

standard fixities were used as the boundary condition in the ABAQUS models.

The shear strength reduction method was used to analyze the slope instability. The strength reduction coefficient of the soil slope reflects that the original shear strength parameters may be reduced enough to trigger the failure of the soil slope [26-28]. The results of the current research reveal that the shear strength of expansive soils will decrease with an increasing number of wet-dry cycles. The cohesion of the expansive soil clearly decreases, but the friction angle is relatively stable with the increase in the number of wet-dry cycles [29]. The reduction in cohesion with the increase in the number of wet-dry cycles is similar to an exponential function relationship, while the friction angle has a decreasing trend with the increase in wet-dry cycles, but the rate of decrease decreases [30]. The soil parameters, as shown in Table 3, were utilized to evaluate the instability of the slope by using ABAQUS. The original model of the soil profile is presented in Figure 10. To simplify, Poisson's ratio of all the soils of the slope was 0.3 .

The two-dimensional model was $190 \mathrm{~m}$ long in the horizontal direction and has a maximum depth of $38 \mathrm{~m}$; a schematic of the original model is shown in Figure 10.

Considering all factors, the Mohr-Coulomb strength criterion was chosen as the failure criterion of the material in this calculation. The soil strength theory of the MohrCoulomb strength criterion is very important in soil mechanics and can reflect the plastic failure characteristics of soil. Because the Mohr-Coulomb strength criterion is simple and practical and the strength parameters of soil are easily measured, this criterion is widely applied in soil mechanics and plasticity theory. At present, many traditional analytical methods, such as slippery line theory, ultimate bearing calculation theory, Earth pressure calculation theory, and structural strength theory, are based on this criterion; its

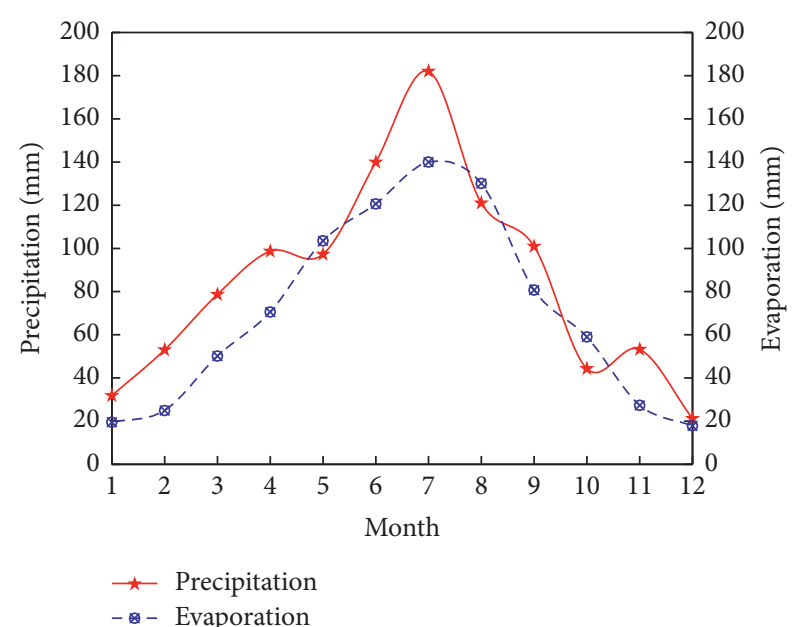

Figure 7: Annual distribution of precipitation and evaporation in Nanjing, East China.

frequent use in practical applications has resulted in the accumulation of experimental data [31-33].

The ABAQUS model was constructed by using a large deformation model. The results of the numerical simulated calculation are presented in Figure 11. The shear strain increment contour plots are mainly used to analyze the trend of slope instability.

As shown in Figure 11, soil layer 2 of the slope is clearly situated in the plastic strain zone, indicating that soil layer 2 has the greatest influence on the slope instability in the FEM models under fully softened conditions. As mentioned above, many tensile cracks happened at the surface of the stone masonry covering the slope soil. The shear strength of the slope soil decreased greatly after the river water level rose and the precipitation intruded in summer, which led to the instability of the soil slope. The desiccation cracks caused by soil swelling-shrinking cycles carried rainwater and river water into the deep soil. The deep low-plasticity clay had a low water conductivity, which prevented the deep intrusion of the water. Consequently, the reduction in fully softened soil shear strength caused by seasonal wet-dry alternation and river level fluctuation conditions in the soil on the slope leads to low-angle low expansive soil slope instability for several years following construction.

The FEM simulation was utilized to determine the safety factor of this soil slope. The factors of safety of the soil slope were calculated to be 1.38 in the first winter and 1.04 in the first summer, which revealed that this soil slope was stable in the first year. In this analysis, slope instability would happen if the factor of safety was equal to 1.0. The factors of safety of the soil slope were calculated to be 0.80 in the third summer, 0.70 in the sixth summer, and 0.65 in the ninth summer after its construction, as presented in Table 4, which indicated that the slope began to be unstable and damaged 3 years following construction due to the drywet cycle and the rise and fall of water level. Therefore, this soil slope might have failed because of the reduction in soil strength resulting from seasonal wet-dry alternation and river level variation events. 


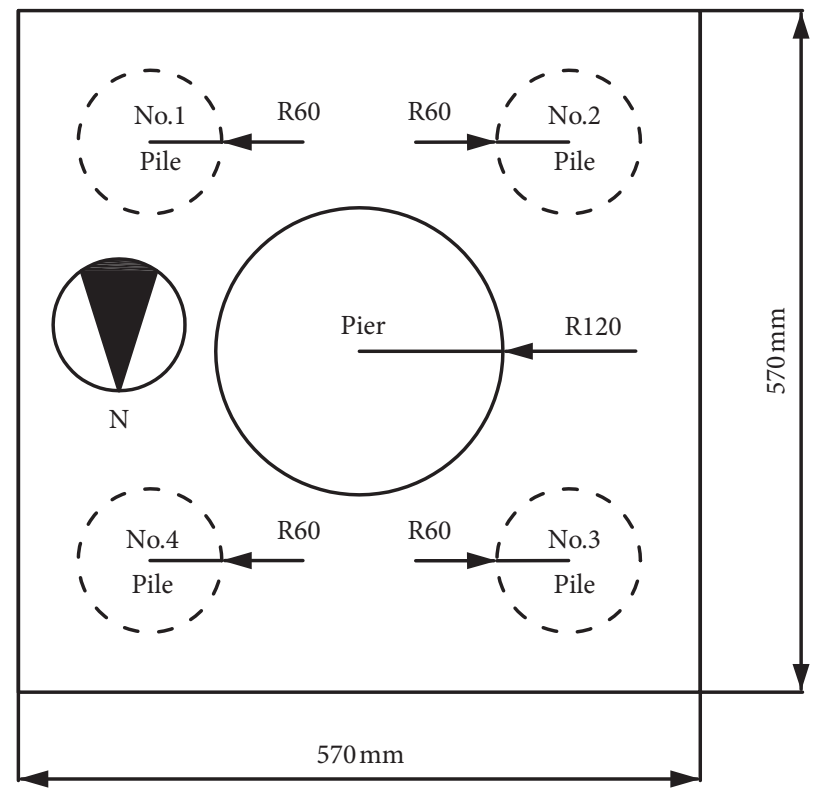

Figure 8: Layout of the pile.

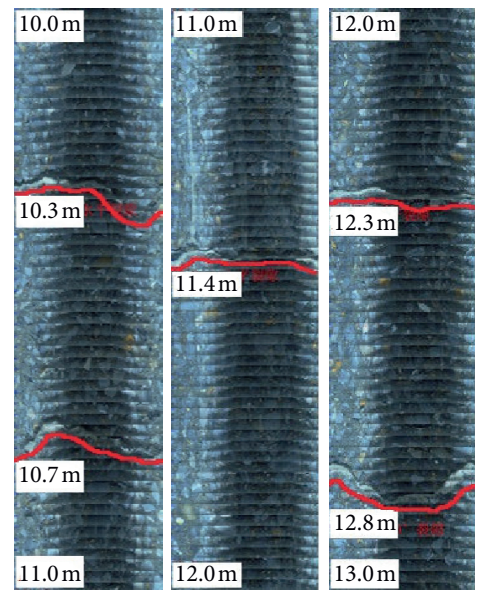

(a)

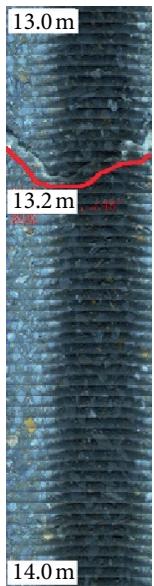

$14.0 \mathrm{~m}$

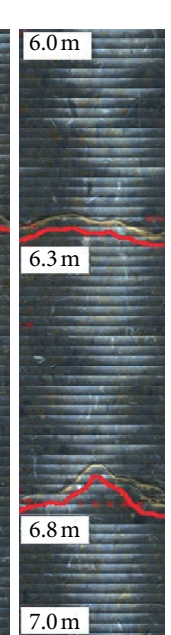

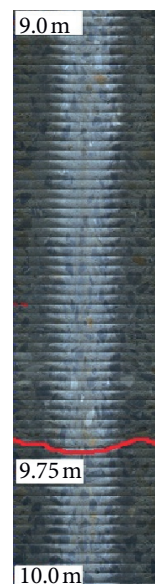

$10.0 \mathrm{~m}=$
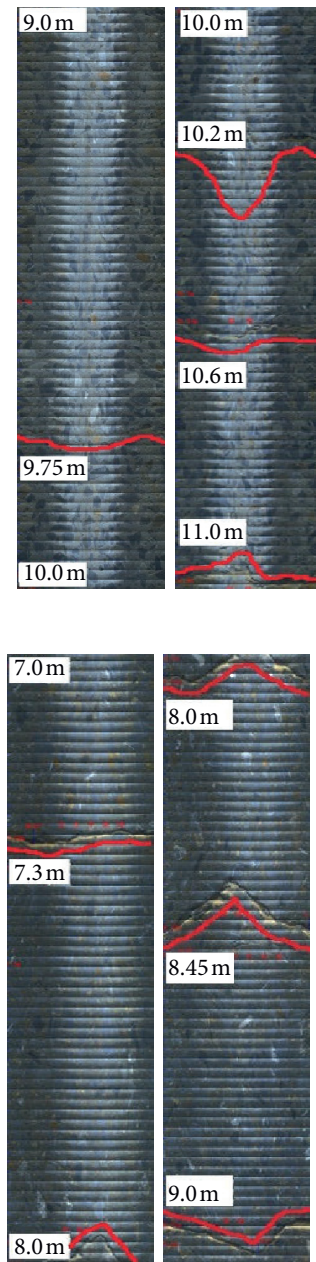

(c)
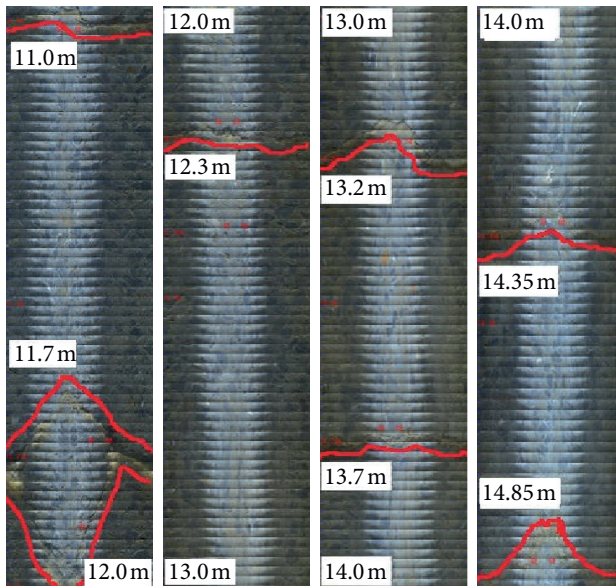

(b)

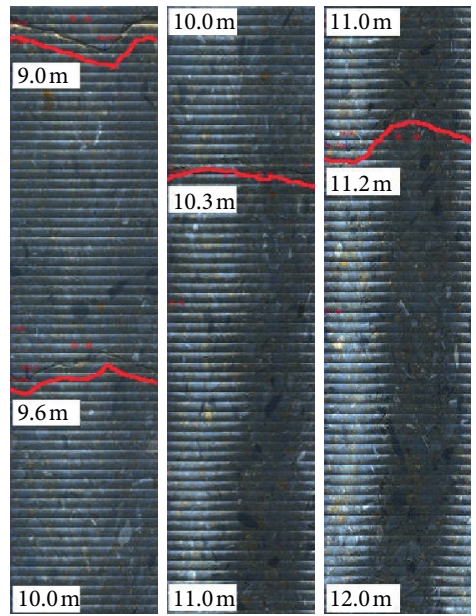

$10.0 \mathrm{~m}$

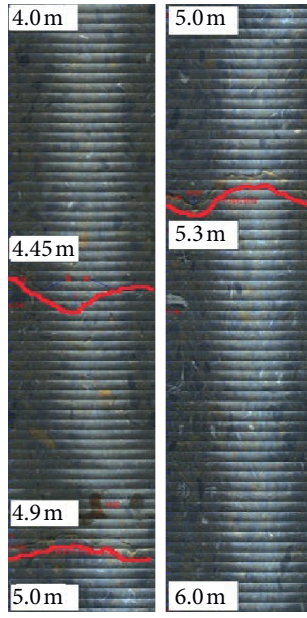

(c)

Figure 9: Results of borehole images: (a) fractures of pile 2 of pier \#3; (b) fractures of pile 4 of pier \#3; (c) fractures of pile 1 of pier \#4. 
TABLE 3: Soil parameters for the slope stability analysis.

\begin{tabular}{|c|c|c|c|c|c|}
\hline Situation & Stratum & $\begin{array}{l}\text { Cohesion } \\
c(\mathrm{kPa})\end{array}$ & $\begin{array}{c}\text { Friction angle } \\
\varphi\left({ }^{\circ}\right)\end{array}$ & $\begin{array}{l}\text { Unit weight } \\
\gamma\left(\mathrm{kN} / \mathrm{m}^{3}\right)\end{array}$ & $\begin{array}{c}\text { Poisson ratio } \\
v\end{array}$ \\
\hline \multirow{3}{*}{ The first winter } & 1 & 37.9 & 17.2 & 19.0 & 0.3 \\
\hline & 2 & 33.6 & 19.0 & 19.8 & 0.3 \\
\hline & 3 & 49.1 & 22.3 & 19.9 & 0.3 \\
\hline \multirow{3}{*}{ The first summer } & 1 & 32.3 & 14.3 & 19.0 & 0.3 \\
\hline & 2 & 30.8 & 14.6 & 19.8 & 0.3 \\
\hline & 3 & 32.0 & 15.1 & 19.9 & 0.3 \\
\hline \multirow{3}{*}{ The third summer } & 1 & 25.8 & 12.9 & 19.0 & 0.3 \\
\hline & 2 & 21.6 & 11.7 & 19.8 & 0.3 \\
\hline & 3 & 28.8 & 13.5 & 19.9 & 0.3 \\
\hline \multirow{3}{*}{ The sixth summer } & 1 & 22.6 & 12.2 & 19.0 & 0.3 \\
\hline & 2 & 15.4 & 11.0 & 19.8 & 0.3 \\
\hline & 3 & 25.6 & 12.8 & 19.9 & 0.3 \\
\hline \multirow{3}{*}{ The ninth summer } & 1 & 19.4 & 11.5 & 19.0 & 0.3 \\
\hline & 2 & 12.3 & 10.2 & 19.8 & 0.3 \\
\hline & 3 & 22.4 & 12.0 & 19.9 & 0.3 \\
\hline
\end{tabular}

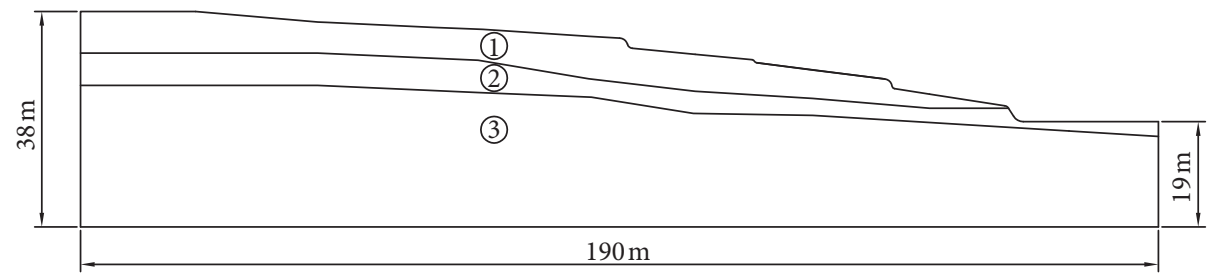

FIGURE 10: Schematic of the original model.

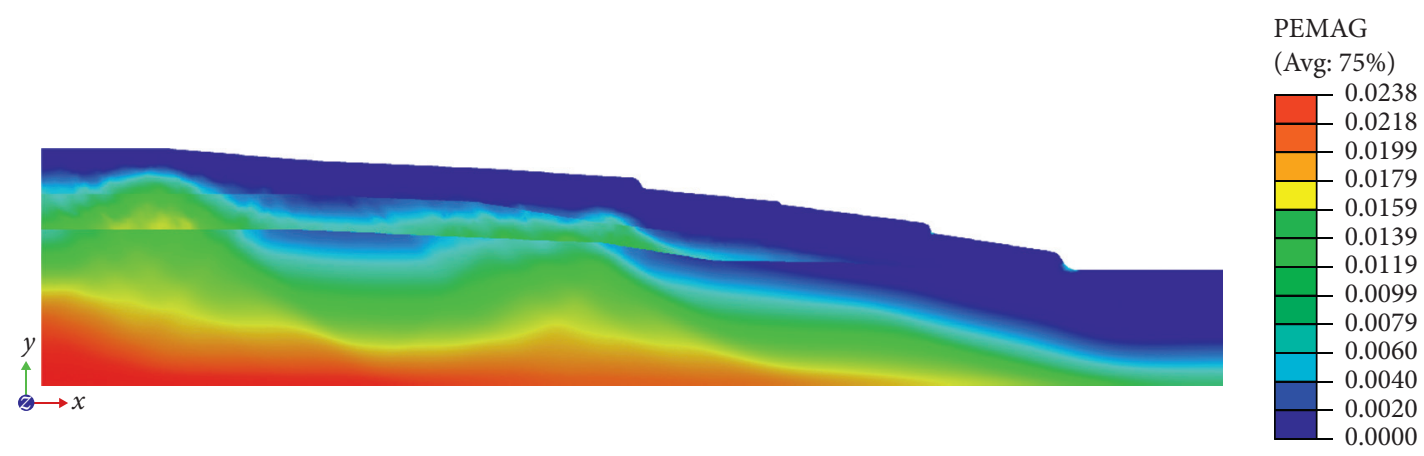

(a)

PEMAG

(Avg: $75 \%)$

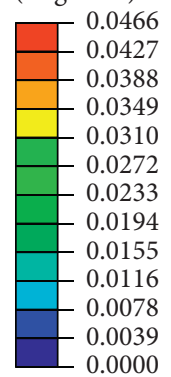

(b)

FIgURE 11: Continued. 


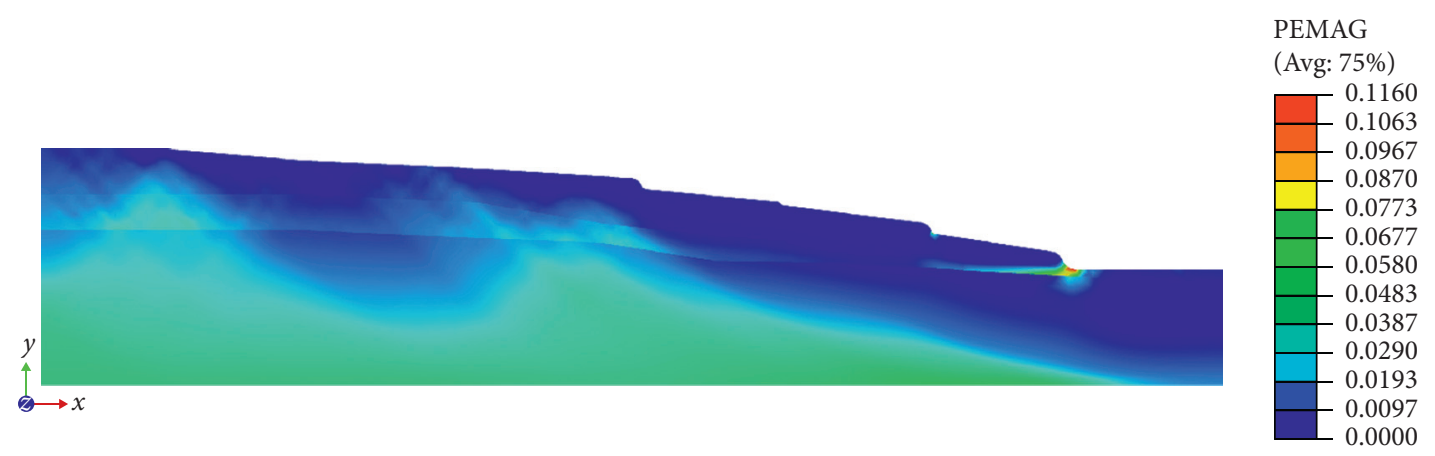

(c)

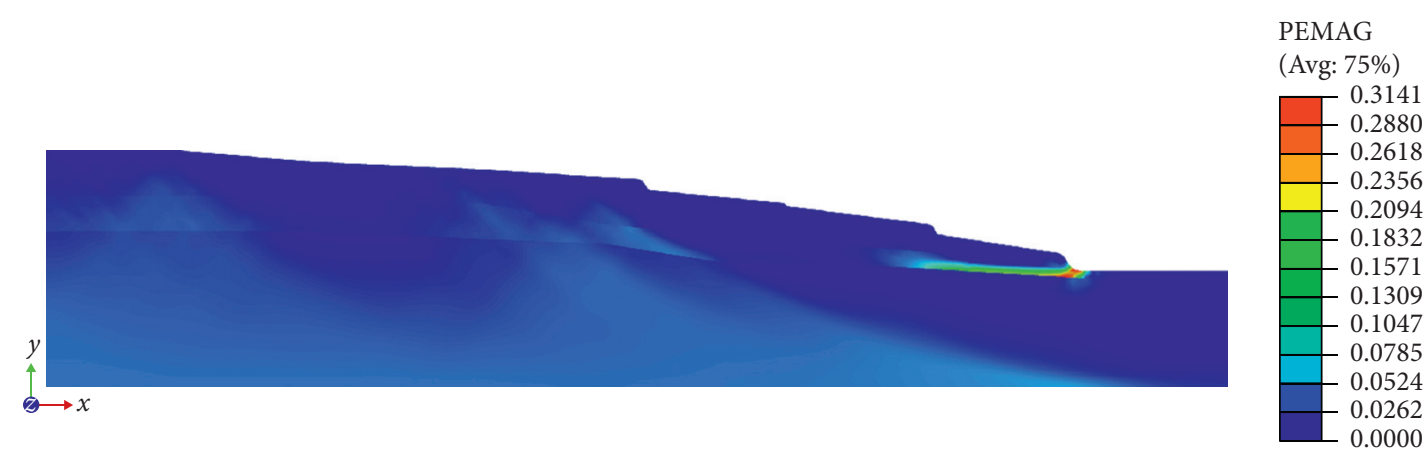

(d)

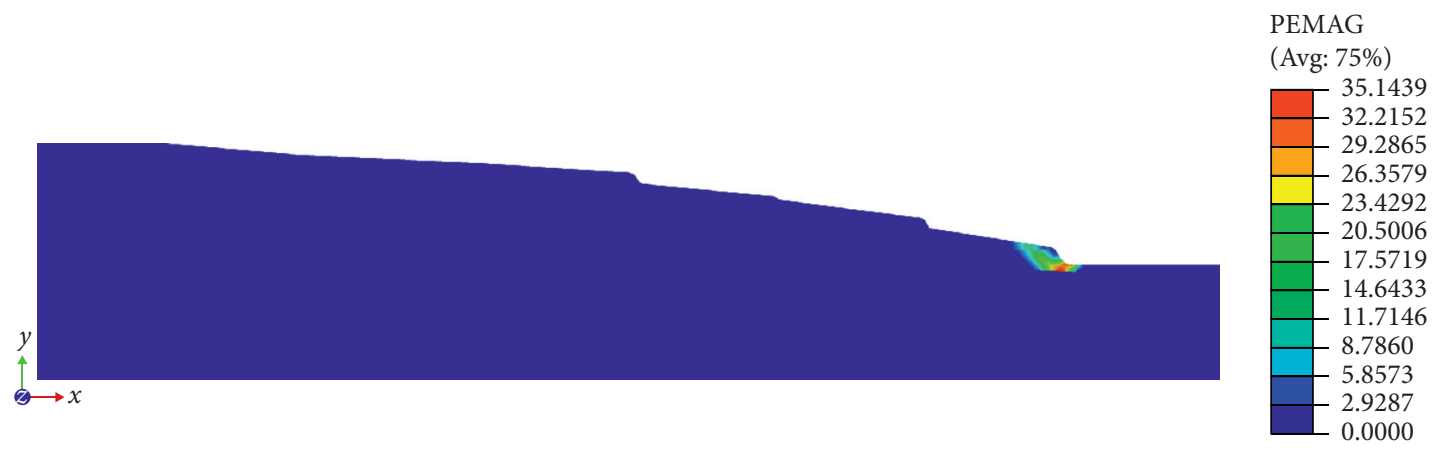

(e)

FIgUre 11: Plastic strain magnitudes at different times. (a) The first winter (FS = 1.38); (b) the first summer (FS = 1.04); (c) the third summer $(F S=0.80)$; (d) the sixth summer $(F S=0.70)$; (e) the ninth summer $(F S=0.65)$.

TABLE 4: The factor of safety of the slope at different times.

\begin{tabular}{lccccc}
\hline Situation & The first winter & The first summer & The third summer & The sixth summer & The ninth summer \\
\hline Factor of safety & 1.38 & 1.04 & 0.80 & 0.70 & 0.65 \\
\hline
\end{tabular}

\section{Conclusions and Discussion}

The instability of a gently sloping low expansive soil slope resulted in many tensile cracks at the surface of the mortar block stones covering the slope soil and lots of fractures in the piles of the bridge foundation. A comprehensive site investigation and a wide variety of tests were implemented, which included geophysical tests, in situ tests, laboratory tests, pile integrity detection, and numerical analysis with finite element method (FEM). The results revealed that this gently sloping expansive soil slope has become unstable due to the events of several seasonal wet-dry alternations and river level variations after its construction.

The low-plasticity clay caused dry shrinkage, which caused the mortar block stones covering the slope soil to undergo tensile cracking during the dry season and develop paths for water to flow into the slope soil during the wet season. The hydraulic conductivity of the slope soil would be changed significantly owing to the tensile cracks in the mortar block stones and the shrinkage cracks in the slope soil, which brought water from the topsoil of the slope to the active zone. According to the study conducted 
by Albrecht and Benson, the permeability of clay soil might increase approximately 500 times during drying [34].

According to the pile integrity detection results, it could be speculated from the many irregular fractures observed in the pile that the soil slope had undergone instability. The data from the FEM numerical analysis indicated that the soil slope began to be unstable and damaged 3 years after its construction. Both seasonal wet-dry alternation and river level fluctuation were responsible for the slope instability, and the typical characteristics of the instability and failure of the gently sloping low expansive soil slope were tractional detachment and slow sliding.

Findings from the study demonstrated that the reduction in expansive soil shear strength with wet-dry cycling plays a very important role in the evaluation of slope instability. Furthermore, the slope stability and the factor of safety decrease with the increase in the number of wet-dry cycles. In this paper, the reduction in soil shear strength resulting from seasonal wet-dry cycles and river level variations led to the instability and failure of the low-angle low expansive soil slope.

\section{Data Availability}

The data used to support the findings of this study are available from the corresponding author upon request.

\section{Conflicts of Interest}

The authors declare that they have no conflicts of interest.

\section{Acknowledgments}

This work was supported by the Key Laboratory of Ministry of Education for Geomechanics and Embankment Engineering, Hohai University (2019008), and the Science and Technology Project for Construction System in Jiangsu Province (2018ZD093).

\section{Supplementary Materials}

A brief description of the title, authors, charts, and manuscript. (Supplementary Materials)

\section{References}

[1] P. Donald, C. Hammes, J. Frami et al., Foundation Design: Principles and Practices, Prentice Hall, Upper Saddle River, NJ, USA, 2001.

[2] J. Nelson and D. J. Miller, Expansive Soils: Problems and Practice in Foundation and Pavement Engineering, John Wiley \& Sons, Hoboken, NJ, USA, 1997.

[3] J. Zheng and H. Yang, Theory and Practice of Expansive Soil Treatment Technology, Renmin Communication Press, Beijing, China, 2004.

[4] B. Cheng-Gang, "Behavior of unsaturated soil and stability of expansive soil slope," Chinese Journal of Geotechnical Engineering, vol. 26, no. 1, pp. 1-15, 2004.

[5] S. Liao, Expansive Soil and Railway Engineering, Chinese Railway Publishing Press, Beijing, China, 1984.
[6] A. Chinkulkijniwat, T. Tirametatiparat, C. Supotayan et al., "Stability characteristics of shallow landslide triggered by rainfall," Journal of Mountain Science, vol. 16, no. 9, pp. 2171-2183, 2019.

[7] Q. Q. Liu and J. C. Li, "Effects of water seepage on the stability of soil-slopes," Procedia IUTAM, vol. 17, pp. 29-39, 2015.

[8] H.-q. Han and S.-s. Chen, "A study on strength and deformation of expansive soils," Chinese Journal of Geotechnical Engineering, vol. 26, pp. 422-424, 2004.

[9] H. Rahardjo, X. Li, D. G. Toll, and E. C. Leong, "The effect of antecedent rainfall on slope stability," in Unsaturated Soil Concepts and Their Application in Geotechnical Practice, pp. 371-399, Springer, 2001.

[10] A. Rahimi, H. Rahardjo, and E.-C. Leong, "Effect of antecedent rainfall patterns on rainfall-induced slope failure," Journal of Geotechnical and Geoenvironmental Engineering, vol. 137, no. 5, pp. 483-491, 2011.

[11] M. S. Khan, S. Hossain, A. Ahmed, and M. Faysal, "Investigation of a shallow slope failure on expansive clay in Texas," Engineering Geology, vol. 219, pp. 118-129, 2017.

[12] S. G. Wright, "Evaluation of soil shear strengths for slope and retaining wall stability analyses with emphasis on high plasticity clays," University of Texas, Austin, TX, USA, FHWA/TX-06/5-1874-01-1, 2005.

[13] J. Johansson and T. Edeskär, "Effects of external water-level fluctuations on slope stability," The Electronic Journal of Geotechnical Engineering, vol. 19, no. K, pp. 2437-2463, 2014.

[14] B. Yang, K. Yin, T. Xiao, L. Chen, and J. Du, "Annual variation of landslide stability under the effect of water level fluctuation and rainfall in the Three Gorges Reservoir, China," Environmental Earth Sciences, vol. 76, no. 16, p. 564, 2017.

[15] Q. Rong, P. HaiZe, H. LingFeng, and C. MengJie, "Considering the effect of reservoir water level lifting on slope stability," Electronic Journal of Geotechnical Engineering, vol. 19, pp. 3291-3300, 2014.

[16] S. Helwany, Applied Soil Mechanics with ABAQUS Applications, John Wiley \& Sons, Hoboken, NY, USA, 2007.

[17] T. G. Abrams and S. G. Wright, "A survey of earth slope failures and remedial measures in texas," Research Report CFHR 3-8-71161-1, University of Texas, Austin, TX, USA, 1972.

[18] H. L. Penman, "Estimating evaporation," Transactions, American Geophysical Union, vol. 37, no. 1, pp. 43-50, 1956.

[19] R. D. Holtz and W. D. Kovacs, An Introduction to Geotechnical Engineering, Prentice Hall, NJ, USA, 1981.

[20] J. D. Nelson, D. D. Overton, and D. B. Durkee, "Depth of wetting and the active zone," in Proceedings of the Expansive Clay Soils and Vegetative Influence on Shallow Foundations, pp. 95-109, Houston, TX, USA, October 2001.

[21] W. Holtz, "Volume change in expansive clay soils and control by lime treatment," in Proceedings of the 2nd International Research and Engineering Conference on Expansive Clay Soils, Texas A\&M University Press, College Station, TX, USA, pp. 157-174, 1969.

[22] K. C. Devkota, J.-E. Ham, and G.-W. Kim, "Characteristics of discontinuity spacing of Yeongdeok granite," Geosciences Journal, vol. 13, no. 2, pp. 161-165, 2009.

[23] D.-s. Bae, K.-s. Kim, Y.-k. Koh, and J.-y. Kim, "Characterization of joint roughness in granite by applying the scan circle technique to images from a borehole televiewer," Rock Mechanics and Rock Engineering, vol. 44, no. 4, pp. 497-504, 2011.

[24] C. Wang, Y. Wang, X. Zou, Z. Han, and S. Zhong, "Study of a borehole panoramic stereopair imaging system," 
International Journal of Rock Mechanics and Mining Sciences, vol. 104, pp. 174-181, 2018.

[25] S. J. Li, X.-T. Feng, C. Y. Wang, and J. A. Hudson, "ISRM suggested method for rock fractures observations using a borehole digital optical televiewer," Rock Mechanics and Rock Engineering, vol. 46, no. 3, pp. 635-644, 2013.

[26] D. V. Griffiths and P. A. Lane, "Slope stability analysis by finite elements," Géotechnique, vol. 49, no. 3, pp. 387-403, 1999.

[27] D. V. Griffiths and R. M. Marquez, "Three-dimensional slope stability analysis by elasto-plastic finite elements," Géotechnique, vol. 57, no. 6, pp. 537-546, 2007.

[28] G. Fei, F. Tiaojin, R. Rongqian, and G. Hongfei, "Analysis of influence of drawdown of reservoir water level on landslide stability using strength reduction method based on ABAQUS," Journal of China Three Gorges University (Natural Sciences), vol. 3, p. 6, 2012.

[29] J. Zhou, H. Xu, and W. Hu, "Impact of wetting-drying cycle effects on stability of expansive soil slopes," Chinese Journal of Geotechnical Engineering, vol. 35, no. S2, pp. 152-156, 2013.

[30] Z. Liu, Z. Wang, and L. Cao, "Strength variation of expansive soil under lateral restraint and wet-dry cycling," Yangtze River, vol. 24, 2012.

[31] Y. Bai and T. Wierzbicki, "Application of extended MohrCoulomb criterion to ductile fracture," International Journal of Fracture, vol. 161, no. 1, pp. 1-20, 2010.

[32] M. Singh, A. Raj, and B. Singh, "Modified Mohr-Coulomb criterion for non-linear triaxial and polyaxial strength of intact rocks," International Journal of Rock Mechanics and Mining Sciences, vol. 48, no. 4, pp. 546-555, 2011.

[33] S. Oberhollenzer, F. Tschuchnigg, and H. FSchweiger, "Finite element analyses of slope stability problems using non-associated plasticity," Journal of Rock Mechanics and Geotechnical Engineering, vol. 10, no. 6, p. 1091, 2018.

[34] B. A. Albrecht and C. H. Benson, "Effect of desiccation on compacted natural clays," Journal of Geotechnical and Geoenvironmental Engineering, vol. 127, no. 1, pp. 67-75, 2001. 